\title{
Potential impacts of climate change on agriculture and the economy in different regions of Brazil
}

\author{
Impactos potenciais das mudanças climáticas sobre a agricultura ea \\ economia nas diferentes regiões do Brasil
}

\author{
Cárliton Vieira dos Santos ${ }^{1}$ (D), Aryeverton Fortes de Oliveira² ${ }^{(1)}$, Joaquim Bento de Souza Ferreira Filho ${ }^{3}$ (1) \\ ${ }_{1}^{1}$ Programa de Pós-graduação em Economia, Universidade Estadual de Ponta Grossa (UEPG), Ponta Grossa (PR), Brasil. \\ E-mail: carlitonsantos@gmail.com \\ ¿Embrapa Informática Agropecuária, Empresa Brasileira de Pesquisa Agropecuária (EMBRAPA), Campinas (SP), Brasil. \\ E-mail: ary.fortes@embrapa.br \\ ${ }^{3}$ Escola Superior de Agricultura "Luiz de Queiroz", Programa de Pós-graduação em Economia Aplicada, Universidade de São Paulo
} (USP), Piracicaba (SP), Brasil. E-mail: jbsferre@usp.br

\begin{abstract}
How to cite: Santos, C. V., Oliveira, A. F., \& Ferreira Filho, J. B. S. (2022). Potential impacts of climate change on agriculture and the economy in different regions of Brazil. Revista de Economia e Sociologia Rural, 60(1), e220611. https://doi.org/10.1590/1806-9479.2021.220611
\end{abstract}

Resumo: Este artigo investiga os impactos socioeconômicos potenciais que as mudanças climáticas projetadas para 2040 podem ter sobre a agricultura e a economia brasileira nas suas diferentes regiões. Para isso, é usado um modelo de EGC inter-regional dinâmico recursivo, calibrado para o ano de 2010. São considerados dois cenários de mudança climática: um Intermediário (RCP4.5) - menos severo - e outro Pessimista (RCP8.5) - mais severo. A principal distinção em relação aos estudos anteriores para o Brasil é o uso de estimativas de perda de área apta para culturas agrícolas, baseadas em projeções para o padrão regional de mudanças climáticas do $5^{\circ}$ relatório do IPCC (o mais recente). Os resultados sugerem que as mudanças climáticas deverão provocar retração no PIB real do Brasil em ambos os cenários, mas esta deverá ser mais intensa no cenário Intermediário; sinalizam também que as perdas serão maiores para as famílias mais pobres e para as regiões cuja economia é mais dependente da agricultura, em particular do cultivo da soja, e que o consumo real e o bem-estar das famílias da região Centro-Oeste e parte do Nordeste (onde a cultura da soja é mais representativa) serão mais afetados do que em outras regiões do Brasil.

Palavras-chave: mudança climática, agricultura, modelo de EGC.

\begin{abstract}
This paper investigates the potential socioeconomic impacts of the climate change projected for 2040 may have on agriculture and on the Brazilian economy, in its different regions. Thus, we used a recursive dynamic interregional CGE model calibrated for 2010. We considered two scenarios of climate change, an Intermediate Scenario (RCP4.5) - less severe - and a Pessimistic Scenario (RCP8.5) - more severe. The main distinction in relation to previous studies performed in Brazil is the estimates of areas that become unviable for agricultural crops, based on projections for the regional pattern of climate change of the 5th and most recent IPCC report. Results suggest that climate change should cause Brazil's real GDP to shrink in both simulated scenarios, but this should be more intense in the Intermediate Scenario. Results also point out that the losses will be greater for poorer households and for regions whose economy is more dependent on agriculture and, in particular, on soybean; and that the actual consumption and well-being of households in the Midwest and part of the Northeast (in the part where the soybean crop is most representative) will be more affected than in other regions of Brazil.
\end{abstract}

Keywords: climate change, agriculture, CGE model.

\section{Introduction}

Climate change has been identified as one of the greatest challenges humanity faces in the $21 \mathrm{st}$ century. The most recent reports from the Intergovernmental Panel on Climate Change (IPCC) presented increasing evidence of rising average temperatures on the planet, changing rainfall 
patterns, increasing frequency of extreme weather events and other meteorological and climatic phenomena arising from the increase in the atmospheric concentration of greenhouse gases (GHG) (Intergovernmental Panel on Change Climate, 2007, 2014). All four GHG concentration and emission scenarios presented in the 5th IPCC Assessment Report (AR5) (Intergovernmental Panel on Change Climate, 2014) - known as Representative Concentration Pathways (RCPs) 2.6, $4.5,6.0$ and 8.5 - support projections of an increase in the average temperature of the planet's surface over this century. The probable increase between years 2081 and 2100 compared to 1986-2005 is expected to be $0.3^{\circ} \mathrm{C}$ to $1.7^{\circ} \mathrm{C}$ in the mildest scenario (RCP2.6), and $2.6^{\circ} \mathrm{C}$ to $4.8^{\circ} \mathrm{C}$ in the most severe scenario (RCP8.5) (Intergovernmental Panel on Change Climate, 2014, p. 10), which can have serious economic and social consequences for different populations, productive sectors, and regions worldwide.

The agricultural sector is highly dependent on environmental conditions, especially temperature and precipitation, and is often identified as the most vulnerable to changes in weather patterns (Zhai et al., 2009). As a result, potential impacts on agriculture have been one of the most studied topics in the climate change literature in recent years (Chalise et al., 2017).

A brief overview of the international literature on climate change and agriculture allows to identify some key aspects in this discussion. First, the impacts of changing climate patterns on agriculture will not be equally distributed around the world, with adverse effects prevailing in tropical and subtropical areas, which predominantly involve developing countries (Darwin et al., 1995; Mendelsohn, 2000; Fischer et al., 2002; Cline, 2007; Quiroga \& Iglesias, 2007; Eboli et al., 2010). Second, regardless of the approach, there are still few studies involving climate change and agriculture focusing on developing countries, considered precisely the most vulnerable (Chalise et al., 2017). Third, computable general equilibrium models have been widely used in those studies, due to their capacity to treat the economy as a complete and interdependent system. Fourth, even less frequent in the literature are studies under a general equilibrium approach dedicated to the analysis of country-specific implications of the relationship between climate change and agriculture, especially for developing countries (for example, Zhai et al., 2009; Ahmed et al., 2011; Elshennawy et al., 2016; Chalise and Naranpanawa, 2016; Chalise et al., 2017).

According to Chalise et al. (2017), computable multiregional general equilibrium models spanning several countries or groups of countries have often been used in international literature to address the links between climate change, agriculture, and the rest of the economy. However, the high degree of regional aggregation of these models impair their ability to deal with country-specific implications of climate change (Chalise et al., 2017). Country-specific analyses of this theme often require greater regional detailing of national economies, especially in the case of countries with a large territorial extension.

In Brazil, the literature relating climate change and agriculture under a general equilibrium approach has predominantly used bottom-up static interregional computable models and climate scenarios derived from the 4th IPCC report (Intergovernmental Panel on Change Climate, 2007). This category of models allows explicitly portraying the well-known Brazilian regional and climatic heterogeneity, as well as dealing with region-specific shocks, but it does not allow verifying the evolution of the economy over time.

This paper aims to investigate the potential socioeconomic impacts that the climate changes projected for 2040 may have on agriculture and on the Brazilian economy as a whole and in its different regions. For this purpose, the most recent IPCC scenarios are used, together with the dynamic TERM-BR model, a computable general equilibrium interregional model with recursive dynamics, calibrated for the base year of 2010 , which seeks to portray in detail a number of aspects of the Brazilian economy. The central hypothesis of the study is that rising temperatures 
and changing rainfall patterns will have negative net effects on agricultural activities, with important consequences for the rest of the economy. Given the regional heterogeneity of crops and production systems that characterize the Brazilian agriculture, it is expected that the impacts will be regionally differentiated, affecting more intensely the regions further to the north and center of the country, which already have higher temperatures, as well as those whose economies are more dependent on agriculture.

The main distinction of this study in relation to the previous ones for Brazil is the use of estimates of loss of area suitable for agricultural crops for the year 2040, based on projections from the 5th and most recent regional climate change pattern IPCC report (Intergovernmental Panel on Change Climate, 2014). The use of these estimates in studies of this nature, as intended here, is still unprecedented.

Brazil is an interesting target of study in this subject for several reasons. First, because most of its territory is located in tropical and subtropical areas - identified as most vulnerable - the country is likely to face serious setbacks due to climate change, as Ferreira Filho \& Moraes (2015) have already pointed out. Second, due to the well-known importance of its agriculture in the generation of domestic jobs and income, the country may suffer serious economic and social consequences resulting from climate changes that justify the effort to investigate them. Third, due to its great relevance in the international market for agricultural products, climate change may affect the performance of the country's exports and imports.

This article consists of 5 sections, in addition to this introduction. Section 2 briefly reviews the empirical literature on the relationship between climate change and agriculture in Brazil. Section 3 contains a brief description of the empirical model used. Section 4 describes the scenario simulation and construction strategy. Section 5 presents the main results and discussion. The sixth section contains the final remarks of the study.

\section{Climate change and agriculture in Brazil}

One of the first studies on the relationship between climate change and agriculture for Brazil was performed by Sanghi et al. (1997). The study sought to assess the possible impacts of climate change on the value of land and the profitability of agriculture. Subsequently, Mendelsohn \& Dinar (1999) discussed the effects of global warming on agriculture in Brazil (and also in India). Nobre \& Assad (2005) analyzed the effects of the increase in temperature at the levels indicated by the IPCC on the ecosystems of the Amazon and on Brazilian agriculture. Deconto (2008) sought to predict the loss of low planting risk area for eight agricultural crops in different regions of Brazil, generating projections of loss of area for the years 2010, 2020, 2050 and 2070 from projections of temperature increase from the 4th IPCC Assessment Report (IPCC, 2007). All of these studies used a partial equilibrium approach.

In another line of studies, Domingues et al. (2008) analyzed the impacts on the Northeast region of a shock in the availability of land suitable for agriculture in each state of the region using a static interregional computable general equilibrium (CGE) model. Domingues et al. (2010) used a dynamic recursive general equilibrium model to analyze the impacts of climate change for Brazil by distinguishing micro-regions and eight agricultural activities. Ferreira Filho \& Moraes (2015) analyzed this issue using a static interregional general equilibrium model, calibrated for the year 2005, considering shocks detailed by agricultural product (eight products) and by region (27 regions). The common element in these studies - in addition to the general equilibrium approach - is that they start from the same future estimates of losses of apt areas made by researchers from the Brazilian Agricultural Research Corporation (Embrapa) and 
partners - more fully communicated in Deconto (2008) - derived from the climatic scenarios of the 4th IPCC Assessment Report (AR4) (Intergovernmental Panel on Change Climate, 2007).

More recently, several studies have emerged in Brazil with an agronomic approach or under a partial equilibrium economic approach, which tried to estimate the direct impact that the climate changes projected for the rest of this century will have on the productivity of the main agricultural crops in the country (for example, Féres et al., 2009; Santos et al., 2011; Marin et al., 2013; Araújo et al. 2014; Walter et al., 2014; Assunção \& Chein, 2016; Pires et al., 2016; Cruz et al., 2016; Verhage et al., 2017; Cera et al., 2017; Tavares et al., 2018). These studies have, although in a very incipient way, allowed the first investigations of the impacts of climate change on Brazilian agriculture, based on the general equilibrium approach, using as inputs these agricultural productivity projections - instead of losses of apt areas - similarly to what has been done for some time in the international literature.

Similarly, Nazareth et al. (2018) used agricultural productivity projections for different regions of Brazil - obtained from Assunção \& Chein (2016) - and for other regions of the world to assess their economic impacts for the country and the rest of the world using a dynamic global CGE model for 5 regions of Brazil and 7 other regions that cover the rest of the world. Tanure et al. (2020) also used the projections of agricultural productivity loss for the period 2030 to 2049 generated by Assunção \& Chein (2016) to analyze the economic impacts of climate change on the region of the Legal Amazon with the use of an interregional CGE model with recursive dynamics. It is noteworthy, however, that there is still a strong limitation for studies of this nature for Brazil, which is the lack of estimates of future agricultural productivity for different agricultural crops covering the entire national territory, as required by the interregional CGE models, predominantly employed in these types of studies for the country. This means that the use of projections of suitable area losses as inputs for the CGE models, used in studies on climate change and agriculture in Brazil, continue to be even more appropriate, as these are generally available in some studies by crops - including in municipal level - for the entire national territory, although infrequently and still restricted to a few crops.

Two attempts to overcome the aforementioned limitation were made by generating their own estimates of the direct effects of climate change on agricultural productivity in Brazil for later use in CGE models, can be found in Haddad et al. (2013) and Souza (2018). In Haddad et al. (2013) the authors analyzed the impact of climatic anomalies observed in 2005 on agriculture and on the Brazilian economy using a physical model integrated with an interregional CGE model. The physical model aimed to estimate the direct impact of anomalies on agricultural productivity, while the CGE model aimed to capture the systemic impacts on the rest of the economy. Along the same lines, Souza (2018) also combined a physical model with an interregional CGE model to analyze the direct and indirect impacts of climate change on agricultural productivity and on the Brazilian economy as a whole at the end of this century. The physical model sought to estimate the direct impacts of climate change on the productivity of six important agricultural crops in the country (soybean, sugarcane, corn, beans, coffee, and orange), taking into account projections of climate change and the 5th IPCC report scenarios. The CGE model used in the study attempted to capture the indirect impacts of these productivity changes on agriculture - treated in the model as an aggregate sector, with no breakdown by products - and on the rest of the Brazilian economy.

\section{Empirical model}

We used the dynamic empirical model TERM-BR, a detailed computable general equilibrium model for the Brazilian economy, interregional, bottom-up, with annual 
recursive dynamics. Its central theoretical structure comes from the TERM model (The Enormous Regional Model) - a static CGE model developed for the Australian economy (Horridge et al., 2005; Horridge, 2012) - and its dynamic extension (Wittwer \& Verikios, 2012). A static version of TERM-BR has been widely used in studies for Brazil (Santos \& Ferreira Filho, 2007; Fachinello \& Ferreira Filho, 2010; Pavão \& Ferreira Filho, 2011; Ferreira Filho \& Moraes, 2015; Diniz \& Ferreira Filho, 2015; Santos \& Ferreira Filho, 2017; Silva \& Ferreira Filho, 2018). The dynamic version of the model for the Brazilian economy, although more recent, has also been used in several studies (Ferreira Filho \& Horridge, 2014; Ferreira Filho et al., 2015; Silva et al., 2017).

The dynamic TERM-BR is composed of 136 sectors (industries), 136 commodities and 27 regions. As they are interregional and bottom-up, these regions are represented by 27 interdependent models, one for each unit of the federation (26 states and the Federal District), interconnected by the goods markets through an interregional trade matrix that registers the regions of origin and destination of goods, and by the primary factors market, with labor and capital being treated as movable between activities and regions. The model is calibrated for the year 2010 - (Diniz, 2019) - using the Brazilian input-output matrix of that year and other official databases that allow a detailed characterization of the Brazilian economy, such as the National Household Sample Survey (PNAD), the Consumer Expenditure Survey (POF), the Municipal Agricultural Production (PAM), all from the Brazilian Institute of Geography and Statistics (IBGE), in addition to numerous other sources. For the purpose of this study, the model was aggregated at the level of 15 regions, 34 commodities and 34 sectors (industries), with 12 of these commodities and sectors belonging to agriculture: 8 of them from agriculture itself (sets of temporary and permanent crops), 3 from livestock, and 1 from forestry and silviculture. The model also distinguishes 3 types of primary factors of production (labor, capital, and land), 10 types of households in each region (categorized by income classes), 10 types of occupations in each region and 2 types of margins (trade and transport). Annex $1 \mathrm{~A}$ presents the 15 regions of the aggregate model (Table $1 \mathrm{~A}$ ) and the Annex $1 \mathrm{~B}$ shows the 34 aggregate sectors (Table 1B).

The theoretical specification of the production structure of each industry in each region in the dynamic TERM-BR model, illustrated in Figure 1, allows each industry to produce one or more goods using domestic or imported commodities, labor of various types, capital, and land (the latter, restricted to only a few sectors). This structure is expressed in the model in a hierarchical ("nested") manner at several levels, which represent the stages of optimization in the production process of firms operating in the economy. The top of the nested structure informs that the production of the different goods and services by each regional industry comes from a Constant Elasticity of Transformation (CET) function, which induces production in favor of that good that has its relative price increased. The next levels of the nested structure indicate that the industries demand, through a Leontief function, composite intermediate inputs - which are aggregated CES (Constant Elasticity of Substitution) of domestic and imported goods - and a composite primary factor. The latter, in turn, is also a CES aggregate of the primary factors land, labor and capital. Labor is a CES aggregate of ten different types of labor. Finally, each domestic input is a CES aggregate from different domestic origins, indicating the possibility of imperfect substitution of these inputs among the domestic origins. Further details on this can be seen in Horridge (2012). 


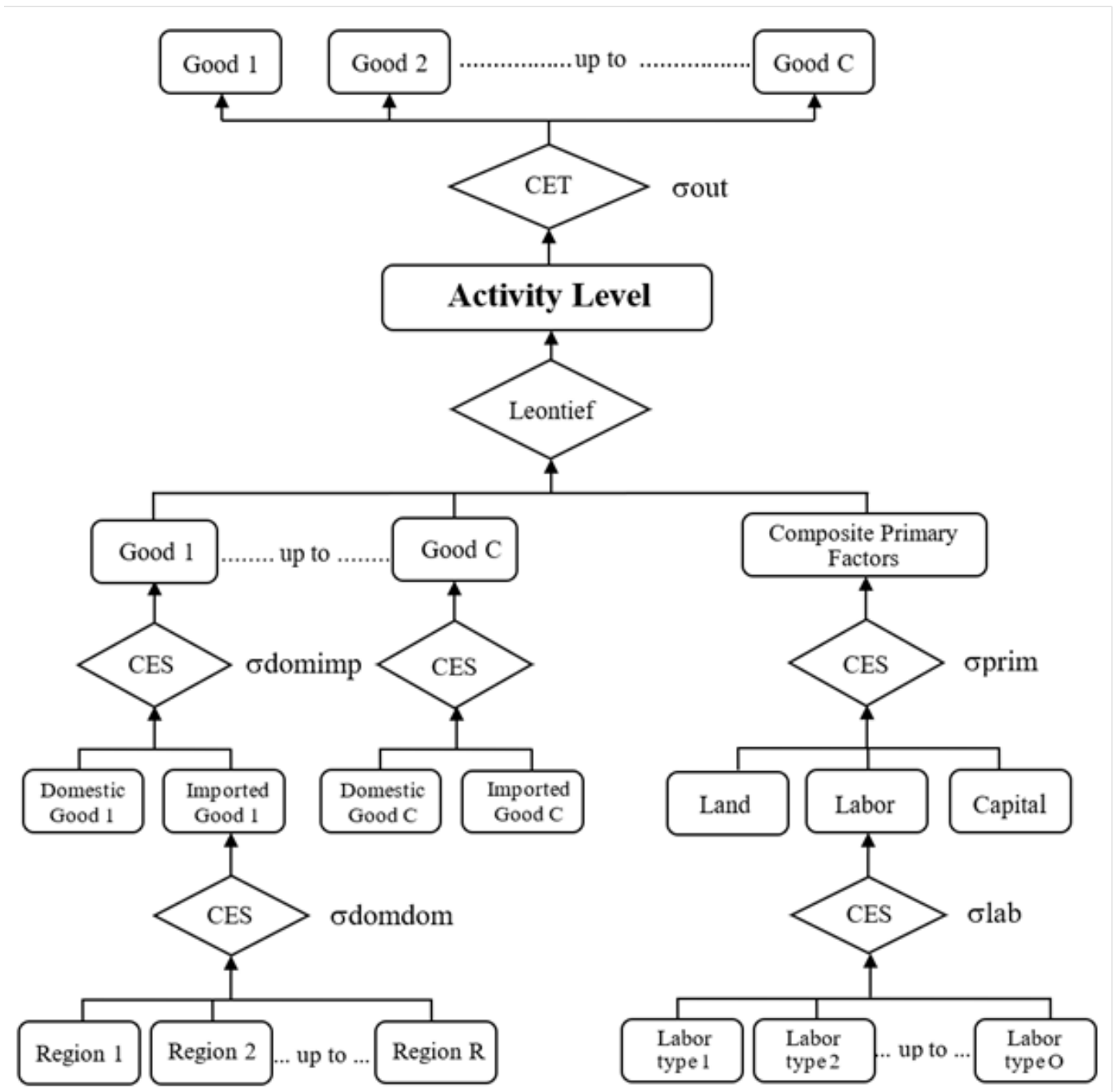

Figure 1 - Nested structure of production at TERM-BR model. Source: Adapted from Horridge (2012) and Santos (2006).

The household demand structure is also represented in the model in a "nested" way, with its consumption possibilities defined by maximizing the Klein-Rubin utility function, subject to a budget constraint. From the maximization of this utility function, a system of demand equations called the linear expenditure system is generated. Based on this system, the expenditure of each good is described as a linear function of the total expenditure and the prices of all goods. Figure 2 shows what would be the first level - from top to bottom - of this "nested" demand structure. At the next level, for each good, households choose between domestic and imported origins, guided by a CES function. This second level, as well as the subsequent ones of the nested demand structure, follow a similar scheme to that presented in Horridge (2012).

The dynamics component of the model basically consists of three mechanisms (Wittwer \& Verikios, 2012): (i) a relationship between investment flow and capital stock, which assumes one year of gestation; (ii) a positive relationship between the investment and the expected profit rate or rate of return in each industry; and (iii) a positive relationship between the variation in real wages and the supply of regional labor. 


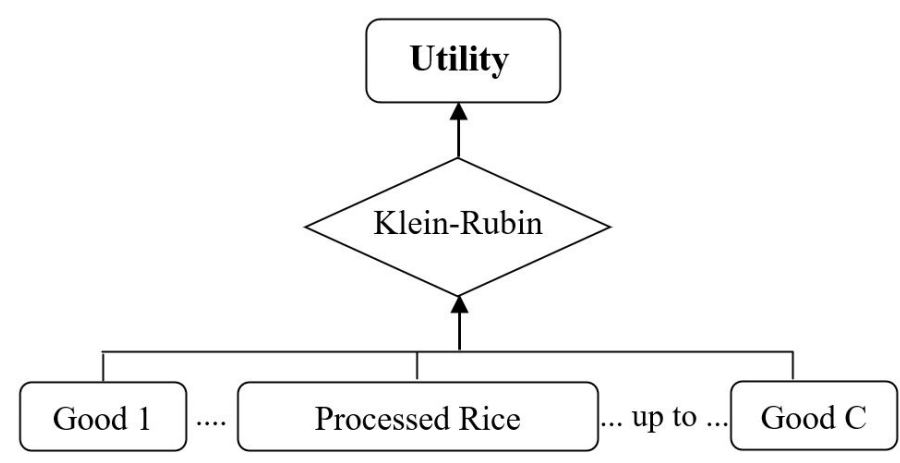

Figure 2 - Top "nest" of the household demand structure at TERM-BR. Source: Adapted from Santos (2006).

\section{Simulation strategy and scenarios}

The implementation of the dynamic CGE model used is done in three stages. First, an initial historical round; second, the projection of a baseline (business-as-usual); third, a simulation of the policy shock, in this case, the climate change shock. The results of interest are the deviations of the policy shock in relation to the reference trajectory.

In the historical simulation, the model is calibrated so as to reproduce the trajectory of the Brazilian economy for the period 2011 to 2017, while providing it with observed variations of some main macroeconomic aggregates and other variables. The variables that received shock at this stage were real GDP, real household consumption, government consumption, real investment, exports (volume), population and labor force (15-69 years), and total area with agricultural activity by region. The data for exports come from the Center for Foreign Trade Studies Foundation (FUNCEX), while the rest are from the Brazilian Institute of Geography and Statistics (IBGE) (Fundação Centro de Estudos do Comércio Exterior, 2018; Instituto Brasileiro de Geografia e Estatística, 2018b). Population and workforce received different shocks by region, following the projections of these variables by Federation Unit, generated by IBGE (Instituto Brasileiro de Geografia e Estatística, 2018a). The evolution of the area with agricultural activity by region was based on the average growth rates observed for agriculture, livestock and forestry in the period 2011 to 2017, calculated from data from the Municipal Agricultural Production (PAM), Municipal Livestock Survey (PPM) and Forestry Activities Survey (PEVS), all of them from IBGE (Instituto Brasileiro de Geografia e Estatística, 2018c). All shocks corresponded to annual percentage changes.

The baseline simulation (business-as-usual) sought to project a growth trajectory for the Brazilian economy from 2018 to 2040, in most cases, based on other studies with CGE models for Brazil, or on available official projections, or on the pattern of behavior observed in previous years for some macroeconomic variables and aggregates for Brazil. The applied shocks represent annual percentage changes, and the shocked variables were real GDP (growth of $2.5 \%$ per year), demand for exports (3.0\% per year), population and labor force (15-69 years). ${ }^{1}$ Population and

\footnotetext{
This value for real GDP was attributed $a d$ hoc. However, it is important to clarify that this rate is close to the average annual growth rate observed in the 22-year period between 1995 and 2017 (the 22 years immediately prior to the period of interest for baseline projection and implementation of the policy shock in this study - 2018 to 2040 - whose extension is also 22 years), 2.3\% per year, according to the authors' calculations based on IBGE data, extracted from IPEADATA (IPEADATA, 2019). For exports, a value of 3.0\% per year was used, which is lower than that observed in the 1995-2017 average. The population and labor force projections were extracted directly from IBGE (Instituto Brasileiro de Geografia e Estatística, 2018a).
} 
labor force received shocks at the regional level, as in the historical simulation. The growth of agriculture and livestock by region was projected based on the assumptions about growth in the supply of agricultural land in Brazil by Ferreira Filho et al. (2018). The shocks were applied to the mentioned variables, and the others were adjusted endogenously to accommodate these shocks.

The policy shock simulation was based on the concept of loss of suitable area - or loss of low-risk area - for agriculture. The concept is adapted from the Agricultural Climate Risk Zoning (ZARC) methodology, developed by Embrapa, and applied in Brazil since 1996 to help indicate the most suitable places and periods for planting each type of agricultural crop. The models that make up the ZARC are widely validated and representative of the effective production conditions, considering the characteristics of climate, soils, plants, and modal management in Brazil. Thus, a suitable or low-risk area combines minimal production conditions and a good chance of success in harvesting the product under consideration (greater than or equal to $80 \%$ ). If the chance of success is less than $80 \%$, the area in question is considered high risk and, therefore, not suitable for a given crop. Based on the ZARC criteria, future risk and fitness scenarios for each crop are constructed combining those municipalities where at least one decade has low risk conditions and the soils have a good capacity to support agricultural crops (clay soils and medium texture).

To build the economy's growth trajectory in order to incorporate climate change projections, results of estimates of losses of suitable or low-risk areas for eight agricultural crops were used for all municipalities in Brazil, for the year 2040, supplied by Embrapa and built according to the ZARC criteria. These estimates were originally conceived as part of a broad study for various sectors of the Brazilian economy called "Projeto Brasil 2040: cenários e alternativas de adaptação à mudança do clima" (Project Brazil 2040: scenarios and alternatives for adapting to climate change) (Brasil, 2015).

It is important to clarify that the estimates of low-risk area loss made by Embrapa involve several methodological steps, whose starting point are the global climatic scenarios. In this case, the global models used to generate these estimates were the Hadley Center Global Environmental Model version 2, from the United Kingdom, with the so-called components of the terrestrial system, Earth System (HadGEM2-ES); and the Model for Interdisciplinary Research on Climate version 5 (MIROC5), from Japan. The results of the climate projections of these global models, within the scope of the mentioned study, were then refined for the different regions of Brazil using the dynamic downscaling technique and the regional climate model ETA, with spatial resolution of $20 \mathrm{~km} \times 20 \mathrm{~km}$ (Brasil, 2016). ${ }^{2}$ As a reference for climate projections, two of the four scenarios that make up the 5th Assessment Report (AR5) of the IPCC were considered (Intergovernmental Panel on Change Climate, 2014), RPC4.5 (intermediate or less severe - with some stabilization of greenhouse gas emissions), and RPC8.5 (pessimistic or more severe - with high levels of greenhouse gas emissions and no mitigation effort). Through this procedure and with the use of the Agricultural Scenarios Simulator (SCenAgri), Embrapa estimated, for the year of 2040, the variations (losses or gains) of suitable areas - or of low risk - for eight of the main agricultural crops from Brazil (cotton, rice, sugarcane, beans, corn, soybean, sorghum, and wheat), having as reference the planted areas of 2012. These eight crops together accounted for $83.41 \%$ of the entire area planted with temporary and permanent crops in Brazil in 2012, and for $67.81 \%$ of the value of agricultural production, according to IBGE data (Instituto Brasileiro de Geografia e Estatística, 2018c). Embrapa's projections were made

2 The regionalized climate model ETA is operationalized at the Center for Weather Forecasting and Climate Studies of the National Institute for Space Research (CPTEC/INPE/MCTI), over all of South America, in the form of numerical weather forecasting, and has been modified to carry out climate simulations (Brasil, 2015). 
for all Brazilian municipalities for each of the two global models, HadGEM2-ES and MIROC5, as well as for each of the scenarios RCP4.5 and RCP8.5, thus generating four different projection scenarios, identified by HadGEM4.5, HadGEM8.5, MIROC.4.5 and MIROC8.5.

As part of the methodological procedures of the present study, the variations in suitable area at the municipal level provided by Embrapa were initially aggregated at the level of 27 regions (26 states of Brazil plus the Federal District) to meet the structural needs of the CGE model used, which demands scenarios at the state level, and at a later stage they were aggregated again at the level of 15 regions to reduce the size of the model and the set of generated results. In turn, the eight crops with projected loss of suitable area - also to meet the needs for compatibility with the CGE model - were represented by the sectors of the aggregate model responsible for their production, thus, instead of the eight crops, shocks of loss of area were applied to six sectors of the aggregate model involving those crops. The Intermediate Scenario (RCP4.5) in the simulations corresponds to the simple arithmetic mean of the variations of apt area projected for 2040 by Embrapa for the scenarios HADGEM4.5 and MIROC4.5. The Pessimistic Scenario (RCP8.5) corresponds to the arithmetic mean of the results of Embrapa's apt area variations for 2040 for the HADGEM8.5 and MIROC8.5 scenarios. Figure 3 summarizes the simulation strategy and the considered scenarios.

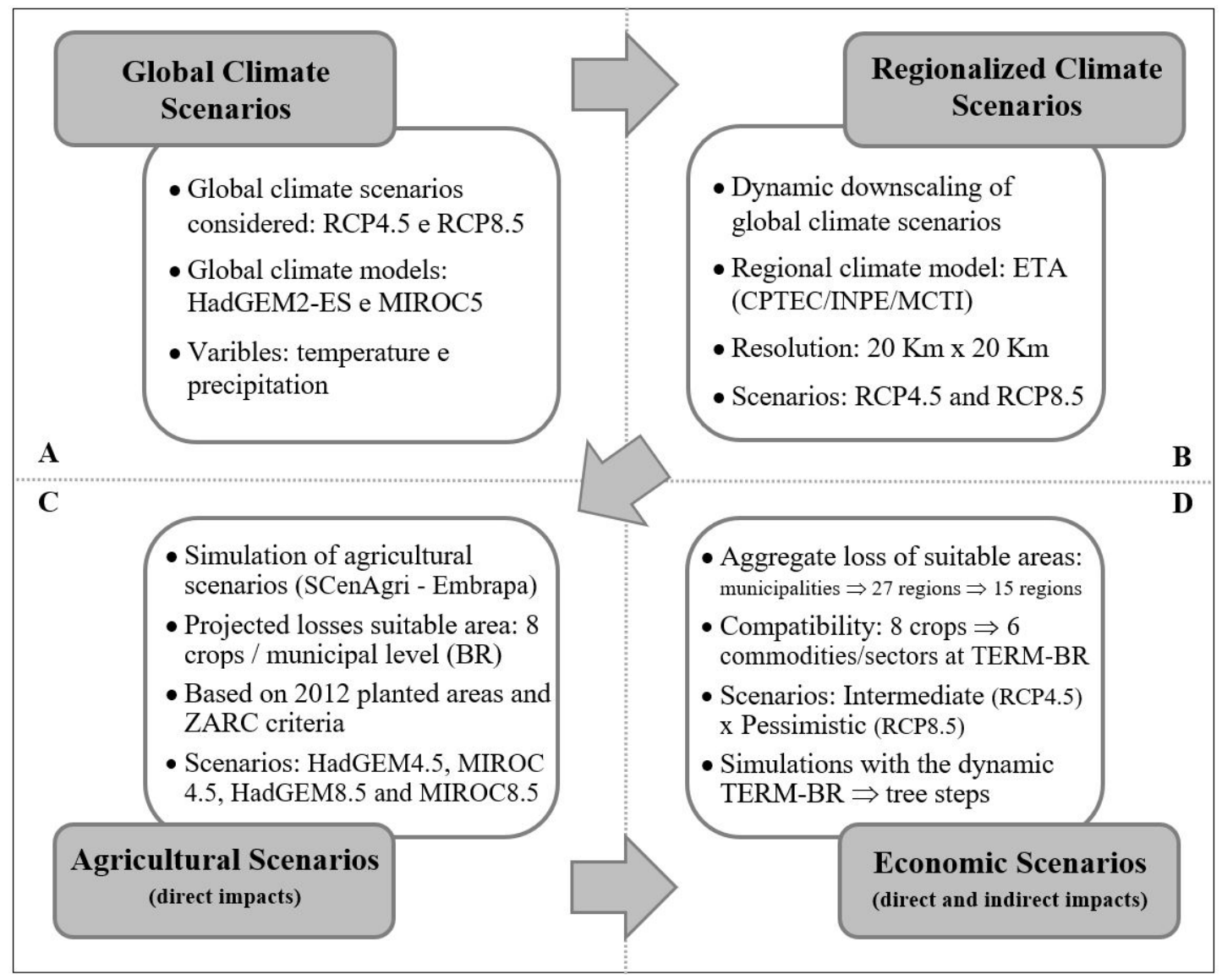

Figure 3 - Synthetic schematic representation of the simulation strategy and scenarios. Note: quadrants A, B and C synthesize the simulation strategies and scenarios from previous studies up to the generation of projections of loss of area suitable for the eight agricultural crops in 2040. Quadrant $\mathrm{D}$ properly synthesizes the simulation strategy and scenarios of the present study. Source: prepared by the authors. 
The final configuration of the scenarios for agriculture used in the simulations of the policy shock, with the values actually used in the shock, is shown in Table 1. In the operationalization of the shocks, the variations in the accumulated apt areas projected for 2040 were transformed into average annual variations and distributed year by year over the period 2018 to $2040 .^{3}$

In addition, it is important to clarify that in the adopted simulation strategy, the area planted with each crop subject to shock - both in the base year and throughout the period up to 2040 - coincides with its apt area. Thus, if the apt area projected for 2040 for a given crop in a given region in the climate change scenario drops by $10 \%$ (compared to the base year), the area planted with the same crop in that region also falls by the same magnitude. In other words, the variations in the apt area for applied shocks are equivalent to the variations in the planted area.

Thus, the causality of the effects of the policy simulation begins with the change in the areas suitable for the various crops, by region. This initial variation in the areas leads to a process of competition for land (and substitution among the other primary factors), as determined by CES functions, illustrated in Figure 1. The subsequent productive reallocation and the transmission of its effects in the different markets lead to the final results, which will be discussed in due course in this article.

Table 1 - Shocks of variation (\%) of suitable area by sector and region - Intermediate and Pessimistic Scenarios - (accumulated values for 2040)

\begin{tabular}{|c|c|c|c|c|c|c|c|c|c|c|c|c|}
\hline \multirow[b]{3}{*}{ Regions } & \multicolumn{6}{|c|}{ Intermediate Scenario (RCP4.5) } & \multicolumn{6}{|c|}{ Pessimistic Scenario (RCP8.5) } \\
\hline & \multicolumn{6}{|c|}{ Sectors } & \multicolumn{6}{|c|}{ Sectors } \\
\hline & 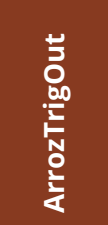 & 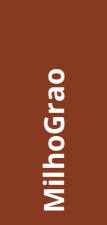 & $\begin{array}{l}\frac{0}{\pi} \\
\frac{1}{1} \\
\frac{1}{0} \\
\stackrel{0}{0} \\
\frac{0}{\alpha}\end{array}$ & 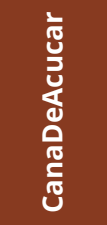 & 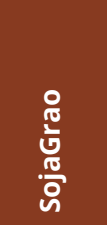 & 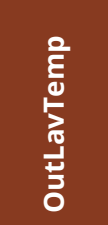 & 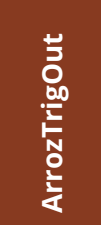 & 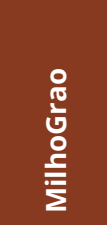 & 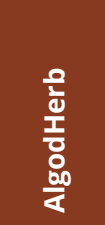 & 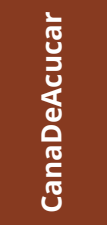 & 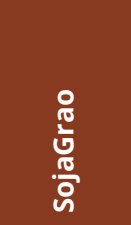 & 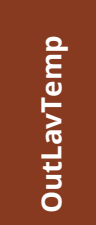 \\
\hline ParaRond & 0.00 & 0.00 & 0.00 & 0.00 & 0.00 & 0.00 & 0.00 & 0.00 & 0.00 & 0.00 & 0.00 & 0.00 \\
\hline RestN & 0.00 & 0.00 & 0.00 & 0.00 & 0.00 & 0.00 & 0.00 & 0.00 & 0.00 & 0.00 & 0.00 & 0.00 \\
\hline MaraToc & 0.00 & 0.00 & 0.00 & 0.00 & -0.24 & 0.00 & -0.06 & 0.00 & 0.00 & 0.00 & -3.88 & 0.00 \\
\hline Piaui & -19.89 & +1.21 & -6.20 & -3.36 & -23.09 & -2.45 & -44.02 & +20.46 & -19.55 & -19.72 & +25.62 & -10.30 \\
\hline RestNE & -10.91 & -0.69 & +1.04 & -0.46 & -24.97 & +0.47 & -16.97 & +2.74 & +0.51 & -0.34 & +8.99 & +3.95 \\
\hline PernAlag & -11.56 & -2.77 & -1.92 & -0.86 & 0.00 & +0.88 & -1.00 & +16.84 & -2.53 & -1.99 & 0.00 & +7.81 \\
\hline Bahia & -33.50 & -28.56 & -25.18 & -24.72 & -17.71 & -14.01 & -11.83 & +22.85 & -19.97 & -22.65 & +148.66 & +5.16 \\
\hline MinasG & -12.02 & -15.16 & -11.49 & 1.94 & -28.77 & -10.83 & -9.53 & -0.45 & -17.35 & -4.04 & -26.32 & -15.61 \\
\hline RestSE & -59.26 & -41.36 & 0.00 & -19.38 & 0.00 & -13.95 & -66.73 & -0.05 & 0.00 & -24.75 & 0.00 & -16.66 \\
\hline SaoPaulo & -31.86 & -17.35 & -0.99 & +1.08 & -49.54 & -5.09 & -29.96 & 0.00 & -0.55 & +1.08 & -39.97 & -3.25 \\
\hline Parana & -19.00 & -12.82 & 0.00 & +82.94 & -90.50 & -6.28 & -28.48 & 0.00 & 0.00 & +82.94 & -48.85 & -6.97 \\
\hline RestS & 0.00 & 0.00 & 0.00 & +82.94 & -64.59 & 0.00 & 0.00 & 0.01 & 0.00 & +82.94 & +232.52 & 0.00 \\
\hline MtGrSul & -26.71 & -19.92 & -0.01 & 0.00 & -68.97 & -5.92 & -25.15 & -0.01 & 0.00 & 0.00 & -41.43 & -2.83 \\
\hline MtGrosso & 0.00 & 0.00 & 0.00 & 0.00 & -1.45 & 0.00 & 0.00 & 0.00 & 0.00 & 0.00 & -1.19 & 0.00 \\
\hline RestCO & 0.00 & 0.00 & 0.00 & 0.00 & -0.13 & 0.00 & -0.05 & 0.00 & 0.00 & 0.00 & -2.53 & 0.00 \\
\hline
\end{tabular}

Source: Authors' own calculations. Note: ArrozTrigOut (Rice, wheat and other cereals); MilhoGrao (Grain maize); AlgodHerb (Cotton and other fibers); CanaDeAcucar (Sugarcane); SojaGrao (Soybean); OutLavTemp (Other products of temporary crops).

Table 1 shows that the shocks applied are predominantly negative (indicating loss of suitable area) in both scenarios, but especially in the Intermediate (RCP4.5). In this scenario,

\footnotetext{
3 It should be noted that the regional models adopted by the National Institute for Space Research (INPE) started to produce information on changes in precipitation, combined with changes in temperature, and these two variables, interacting, can produce changes in the results of agroclimatic modeling compared to other scenarios produced by Embrapa in the past.
} 
the most severe negative shocks - in terms of absolute magnitudes - are for SojaGrao, followed by ArrozTrigOut and MilhoGrao, in several regions of the country. In regional terms, in the Intermediate Scenario, the most severe negative shocks occur in almost the entire Northeast region, in the entire Southeast region, in practically the entire South region, and in part of the Midwest region (particularly MtGrSul). In this scenario, there are more expressive positive shocks (gain of suitable area) only for SojaGrao in the South region (Parana and RestS).

In the Pessimistic Scenario (RCP8.5), although negative shocks also predominate, there is a higher frequency of positive shocks than in the Intermediate. In this scenario (Pessimistic), the most severe negative shocks - in terms of absolute magnitudes - are for ArrozTrigOut, and in some cases, for SojaGrao. In regional terms, the most frequent and intense negative shocks in absolute magnitude in such a scenario occur throughout the Southeast region, part of the Northeast region (Piaui and Bahia), part of the South (Parana) and part of the Center-West region (particularly MtGrSul). For MilhoGrao, positive shocks predominate (gain of suitable area); however, the most expressive positive shocks occur for SojaGrao in Resto do Sul (RestS), Bahia and Piaui. The shocks to CanaDeAcucar in the South (Parana and RestS) are also positive and severe in both scenarios. This is especially due to the good response of the crop to increases in temperature and $\mathrm{CO}_{2}$ concentration during a certain period. Over a longer time horizon beyond 2040 - the crop would react badly to the continued rise in temperature and contraction of $\mathrm{CO}_{2}$, which would exceed the optimum levels, implying a reduction of apt area.

It is important to note that in addition to the absolute magnitudes of these shocks in the suitable area, the structure of the sectoral composition of the economic activities in each region has a determining role in the final expected impact of the shocks on the different Brazilian regions. In particular, it is important to know in advance the participation shares of each agricultural activity portrayed in the model - and of all of them - in the production value of each regional economy in the base year (2010). Table 2 provides this information for the eight sectors of agriculture - temporary and permanent crops - in the value of regional production in the base year (2010) for each of the 15 aggregated regions in the model.

Table 2 - Share of the agricultural sectors in the value of regional production of all activities in the base year (2010)

\begin{tabular}{|c|c|c|c|c|c|c|c|c|c|}
\hline \multirow[b]{2}{*}{ Regions } & \multicolumn{9}{|c|}{ Sectors } \\
\hline & 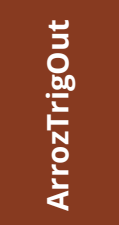 & $\begin{array}{l}\stackrel{\circ}{\circlearrowright} \\
\text { 늘 } \\
\text { 을 }\end{array}$ & 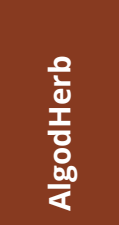 & 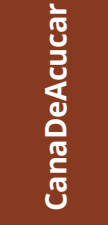 & 은 & 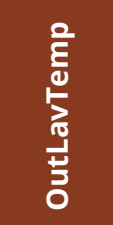 & 迹 & 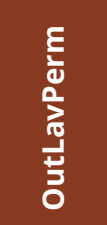 & 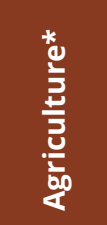 \\
\hline ParaRond & 0.0017 & 0.0027 & 0.0001 & 0.0005 & 0.0034 & 0.0155 & 0.0031 & 0.0091 & 0.0361 \\
\hline RestN & 0.0008 & 0.0007 & 0.0003 & 0.0019 & 0.0015 & 0.0109 & 0.0005 & 0.0023 & 0.0189 \\
\hline MaraToc & 0.0064 & 0.0037 & 0.0014 & 0.0060 & 0.0206 & 0.0111 & 0.0003 & 0.0016 & 0.0511 \\
\hline Piaui & 0.0021 & 0.0048 & 0.0009 & 0.0011 & 0.0158 & 0.0068 & 0.0005 & 0.0016 & 0.0336 \\
\hline RestNE & 0.0003 & 0.0015 & 0.0001 & 0.0040 & 0.0007 & 0.0081 & 0.0002 & 0.0056 & 0.0205 \\
\hline PernAlag & 0.0001 & 0.0003 & 0.0001 & 0.0176 & 0.0005 & 0.0047 & 0.0002 & 0.0057 & 0.0292 \\
\hline Bahia & 0.0001 & 0.0034 & 0.0056 & 0.0021 & 0.0082 & 0.0133 & 0.0031 & 0.0173 & 0.0531 \\
\hline MinasG & 0.0002 & 0.0036 & 0.0002 & 0.0050 & 0.0032 & 0.0076 & 0.0145 & 0.0022 & 0.0365 \\
\hline RestSE & 0.0000 & 0.0000 & 0.0000 & 0.0005 & 0.0001 & 0.0006 & 0.0019 & 0.0008 & 0.0039 \\
\hline SaoPaulo & 0.0000 & 0.0005 & 0.0000 & 0.0074 & 0.0004 & 0.0010 & 0.0005 & 0.0028 & 0.0126 \\
\hline Parana & 0.0037 & 0.0084 & 0.0000 & 0.0053 & 0.0208 & 0.0119 & 0.0017 & 0.0021 & 0.0539 \\
\hline RestS & 0.0070 & 0.0038 & 0.0000 & 0.0003 & 0.0112 & 0.0125 & 0.0000 & 0.0033 & 0.0381 \\
\hline MtGrSul & 0.0016 & 0.0132 & 0.0042 & 0.0293 & 0.0471 & 0.0046 & 0.0002 & 0.0003 & 0.1005 \\
\hline MtGrosso & 0.0035 & 0.0144 & 0.0327 & 0.0086 & 0.1178 & 0.0107 & 0.0003 & 0.0020 & 0.1900 \\
\hline RestCO & 0.0004 & 0.0035 & 0.0023 & 0.0051 & 0.0126 & 0.0063 & 0.0002 & 0.0008 & 0.0312 \\
\hline
\end{tabular}

Source: Model database. Note: $\left(^{*}\right)$ Temporary crops + Permanent crops. 
The importance of agriculture for the economies of Mato Grosso (MtGrosso) and Mato Grosso do Sul (MtGrSul) stands out, with a share of $19 \%$ and $10 \%$ in the total value of regional production, respectively. These regional economies are, for this reason, strongly dependent on the performance of agricultural activity for the generation of income and the formation of regional GDP. It is also important to realize the relevant role of soybean cultivation for these regions: the SojaGrao sector alone accounts for $11.8 \%$ of the value of production in Mato Grosso and $4.7 \%$ of the value of production in Mato Grosso do Sul in the base year (2010). It should be noted that although these activities - soybean cultivation and agriculture as a whole - are also traditional in Paraná (Parana) and Resto do Sul (RestS), these regions (especially the state of Paraná) have a more diversified economy and, therefore, are less dependent on these activities, compared to Mato Grosso and Mato Grosso do Sul.

Finally, it is important to note that in the policy shock simulations implemented in this study, the total land stock per region was kept fixed, but substitution was allowed among agricultural crops and among land-using activities (sectors) in each region, involving 11 sectors of the model. This means that even agricultural activities that were not subject to shocks in the simulation (CafeGrao and OutLavPerm) and other land-using activities (BovOutrAnim, LeitVacOuAni and ExplFlorSilv) may suffer variations - upward or downward - as a result of the resource allocation process after the policy shock.

\section{Results}

The results of the simulations for the main selected macroeconomic variables are shown in Table 3. As observed, the real GDP falls in both climate change scenarios - compared to the baseline - and the drop is greater in the Intermediate Scenario than in the Pessimistic (RCP8.5). This fall in both scenarios stems from the predominance of losses of area suitable for agriculture in the implemented policy shocks. This negatively affects the performance of the components of the real GDP - especially household consumption and investment - and, therefore, its aggregate result. In the Intermediate Scenario all components of GDP registered a drop in the accumulated for 2040, with household consumption accounting for approximately $47 \%$ of the total drop in the real GDP, the gross fixed capital formation (called investment, in the model) together with the variation in inventories, it accounts for around $33 \%$ of this total, and net exports for the remaining 20\%. In the Pessimistic Scenario, in contrast to the other components of the GDP, net exports grew, contributing to mitigate the fall in the real GDP in this scenario compared to the Intermediate Scenario, accumulated in 2040.

Another important result is that the simulated impacts of climate change scenarios on the main macroeconomic aggregates will be small (between $-1 \%$ and $+1 \%$ accumulated in 2040). In some cases, this differs greatly from the magnitudes of the results found in other studies for Brazil under a general equilibrium approach, but direct comparisons among different studies require caution, since the set of criteria used in the simulations (scenarios, closures, databases, model, time horizons, etc.) are often quite different from each other. For example, Domingues et al. (2010), when analyzing the impacts of climate change on the Brazilian economy for the year 2050, estimated losses of around $0.5 \%$ in the real GDP in one of the scenarios (scenario A2, from the 4th Assessment Report of the IPCC) and $2.3 \%$ in another scenario (B2). Ferreira Filho \& Moraes (2015) - which is the study that methodologically is closest to the present study - found a $0.28 \%$ retraction of the real GDP for Brazil in one of the simulated scenarios (A2) for the year 2020, and a fall $1.12 \%$ in another, less severe (B2) scenario for 2070. However, the authors additionally imposed a retraction in the total area of agriculture in each region equivalent to 
the total loss of low-risk area in the region with the crops that were initially the object of the shocks, assuming that those areas would not be occupied by another crop, which may have, to some extent, overestimated the negative impacts on the agricultural sector and on GDP. In contrast, in the simulations implemented in the present study, we admitted the possibility of substituting one crop for another, and this substitution was treated endogenously. In particular, livestock and silviculture assume a prominent role in this process in the Intermediate Scenario, occupying a significant part of the areas lost by agriculture. ${ }^{4}$ In the Pessimistic Scenario, the areas lost by some crops are completely replaced by other agricultural crops.

Table 3 - Impact of climate change on selected macroeconomic variables - Brazil - for both simulated climate change scenarios (percentage change accumulated up to 2040)

\begin{tabular}{lcc}
\multicolumn{1}{c}{ Variables } & $\begin{array}{c}\text { Intermediate Scenario } \\
\text { (RCP4.5) }\end{array}$ & Pessimistic Scenario (RCP8.5) \\
Real household consumption & -0.12 & -0.07 \\
Real investment & -0.18 & -0.10 \\
Exports (volume) & -0.42 & +0.15 \\
Imports (volume) & -0.30 & +0.10 \\
Real GDP & -0.15 & -0.04 \\
Aggregate employment & 0.00 & 0.00 \\
Real wage & -0.05 & -0.09 \\
Capital stock & -0.08 & -0.03 \\
\hline
\end{tabular}

Source: Model results.

In the Intermediate Scenario (RCP4.5) the volume of aggregate exports would experience the greatest drop among all macro-variables. This is not surprising, given the large share of agricultural products in total Brazilian exports and the fact that these products have been subject to shocks from a predominantly negative apt area - increased risk - in policy shock simulations, which ends up affecting the final results of the model. This projected retraction of total Brazilian exports is strongly influenced by the significant expected decrease in production and national soybean exports in the simulation of this scenario, of the order of $28.70 \%$ and $51.19 \%$, respectively, in the face of climate change. In the Pessimistic Scenario (RCP8.5), the good performance of total exports and net exports in Brazil projected for the accumulated in 2040 can be attributed especially to the difference in the picture for soybean in the comparison of the two scenarios, which was a loss of suitable area in the Intermediate Scenario, and in this scenario (Pessimistic) is gain.

The simulations indicate that few activities among the eight belonging to agriculture would show a relatively marked variation in production over the period when compared to the others. Table 4 shows that in the Intermediate Scenario (RCP4.5), the ArrozTrigOut and CanaDeAcucar industries are the ones that would register the largest expansions in production among the eight highlighted activities. For example, even though the case of ArrozTrigOut started from a loss of suitable area for simulating this scenario, the combination of direct and indirect effects resulting from the allocation of resources and the change in relative prices - of inputs and products - would lead to an expansion of production in this sector. This growth is mainly due to the strong expansion of the area (land use) with this activity (9.49\% accumulated in 2040, in the Intermediate Scenario, not shown in the tables), which occurs in substitution for the

4 The area of land with activities related to beef and dairy farming (sectors BovOutrAnim and LeitVacOuAni in the model) grew $3.00 \%$ and $3.70 \%$, respectively, in the accumulated in 2040, in relation to the baseline, in the Intermediate Scenario. Silviculture (which is part of the ExplFlorSilv sector), in this same scenario, grew 5.05\%. 
area with soybean in the country, which shows a retraction $(-39.90 \%$ accumulated in 2040 in the Intermediate Scenario). This replacement of the soybean area (SojaGrao sector) mainly by rice (ArrozTrigOut) occurs especially in regions that were also important rice producers, such as Parana and RestS, in which the soybean area release allows the rice to expand in these regions. The good performance of the CanaDeAcucar sector, on the other hand, is due to the improvement of the crop under conditions of increased temperature and $\mathrm{CO}_{2}$ concentration in the study's horizon. On the other hand, the SojaGrao activity in this Intermediate Scenario would accumulate a drop of more than $30 \%$ in its production, compared to the baseline scenario. This drop would be the biggest among the eight agricultural activities over the period under study. In the Pessimistic Scenario (RCP8.5), the CanaDeAcucar and CafeGrao sectors are the ones that would register the biggest expansions in production among the analyzed properly agricultural activities. It is important to remember that CafeGrao was not subject to a policy shock in the simulations carried out. This activity will benefit - in both scenarios - from the indirect effects of the resource allocation process induced by climate change, in particular, by the replacement of areas previously occupied by other crops. The ArrozTrigOut activity, on the other hand, should register a strong retraction in this second scenario, in comparison with the baseline, in particular yielding area, for example, to CafeGrao in the regions where the two crops already coexisted.

Table 4 - Variation (\%) in the production of the agricultural sectors (accumulated values up to 2040)

\begin{tabular}{lcc}
\multicolumn{1}{c}{ Agriculture Sectors } & $\begin{array}{c}\text { Intermediate Scenario } \\
\text { (RCP4.5) }\end{array}$ & $\begin{array}{c}\text { Pessimistic Scenario (RCP8.5) } \\
\text { ArrozTrigOut }\end{array}$ \\
MilhoGrao & +6.77 & -10.48 \\
AlgodHerb & +2.28 & -0.45 \\
CanaDeAcucar & -1.47 & -3.05 \\
SojaGrao & +3.89 & +2.01 \\
OutPrLavTemp & -30.26 & +0.24 \\
CafeGrao & +2.29 & -1.54 \\
OutPrLavPerm & +2.42 & +0.83 \\
\hline
\end{tabular}

Source: Model results.

The results shown in Table 5 reveal major differences in the behavior of the real GDP among Brazilian regions as a result of the projected climate changes for 2040. They suggest that in the Intermediate Scenario (RCP4.5) there should be a drop in the real GDP accumulated in 2040 to 13 of the 15 regions detailed in the model, and that the states of Mato Grosso do Sul (MtGrSul), Paraná (Parana), Mato Grosso (MtGrosso) and Bahia are, in this order, those that would present the greatest retractions in the real GDP in relation to the trajectory defined in the baseline. It is noteworthy that these four states, in addition to having a very important part of their economies in agriculture - especially Mato Grosso and Mato Grosso do Sul - are also important soybean producers - the main product of Brazil's export agenda in natura (soybean) and also important in the form of bran, oil and as a raw material for chicken meat exported by the country. Thus, we conclude that the process of intersectoral resource allocation driven by climate change in this Intermediate Scenario would not be enough to compensate for the losses in GDP resulting from the retraction in the area suitable for soybean cultivation in these four Brazilian states. In all of them, the real GDP is expected to fall more than at the national level. For the other regions of the model, where soybean cultivation is inexistent or not very representative in the regional agricultural or economic activity, or where it is significant, but the 
process of allocating resources to other activities almost compensates for the losses resulting from the retraction of area with soybean, the impacts on regional GDP should be smaller, according to the simulation results.

Table 5 also shows, in the last two columns, a sensitivity analysis, performed with the values of a central parameter in this analysis, the elasticity of substitution among primary production factors (oprim, in Figure 1), for the activities of agriculture, and for the Intermediate Scenario. This analysis is performed by varying by $10 \%$ more or less the value of that elasticity. As observed, the results vary very little for most states. The exception is the state of Mato Grosso, which presents a greater variation among these simulations. Again, this result is associated with soybean crop, which is of great importance in the state. Although the magnitude of the variation is different, however, its direction is the same in all three cases. ${ }^{5}$

Table 5 - Variation (\%) in real regional GDP and sensitivity analysis (accumulated values up to 2040).

\begin{tabular}{|c|c|c|c|c|}
\hline \multirow{2}{*}{ Region } & $\begin{array}{l}\text { Pessimistic } \\
\text { Scenario }\end{array}$ & $\begin{array}{c}\text { Intermediate } \\
\text { Scenario }\end{array}$ & $\begin{array}{c}\text { Intermediate } \\
\text { Scenario }\end{array}$ & $\begin{array}{c}\text { Intermediate } \\
\text { Scenario }\end{array}$ \\
\hline & (RCP8.5) & (RCP4.5) & $\begin{array}{l}\text { (RCP4.5) Elast. } \\
\text { Subst. } 10 \% \text { less }\end{array}$ & $\begin{array}{l}\text { (RCP4.5) Elast. } \\
\text { Subst. } 10 \% \text { more }\end{array}$ \\
\hline ParaRond & +0.02 & -0.01 & -0.01 & -0.01 \\
\hline RestN & +0.01 & 0.00 & 0.01 & 0.00 \\
\hline MaraToc & -0.02 & -0.03 & -0.01 & -0.04 \\
\hline Piaui & +0.02 & -0.11 & -0.10 & -0.11 \\
\hline RestNE & -0.01 & -0.04 & -0.04 & -0.04 \\
\hline PernAlag & -0.07 & -0.02 & -0.02 & -0.02 \\
\hline Bahia & +0.03 & -0.20 & -0.21 & -0.19 \\
\hline MinasG & -0.04 & -0.03 & -0.03 & -0.03 \\
\hline RestSE & -0.06 & -0.09 & -0.09 & -0.09 \\
\hline SaoPaulo & -0.01 & -0.04 & -0.04 & -0.04 \\
\hline Parana & +0.07 & -1.24 & -1.26 & -1.22 \\
\hline RestS & -0.23 & -0.09 & -0.08 & -0.10 \\
\hline MtGrSul & -0.83 & -1.98 & -2.00 & -1.95 \\
\hline MtGrosso & -0.09 & -0.37 & -0.17 & -0.47 \\
\hline RestCO & -0.01 & 0.00 & 0.01 & -0.01 \\
\hline
\end{tabular}

Source: Model results.

The results of the simulations can also be analyzed from a more aggregated regional perspective, at the level of 6 major regions (North, Northeast, SaoPaulo, Rest of the Southeast, South and Midwest). For the Intermediate Scenario, the drop in the real GDP - not shown in the tables - would be more intense in the South $(-0.51 \%)$ and Midwest $(-0.29 \%)$ regions. For the Northeast region, the shock of climate change portrayed in the Intermediate Scenario would cause a fall of $0.09 \%$ in the real GDP. For the other regions it would cause a fall in the Rest of the Southeast $(-0.07 \%)$, a fall for SaoPaulo $(-0.04 \%)$, and for the North region there would be no change in the real GDP accumulated until 2040, compared to the scenario base. These aggregate results reinforce the already mentioned argument that the negative impacts of climate change - with regard to shocks on agriculture - will be greater for those regions whose economies are more dependent on agriculture in the composition of their production value, especially soybean.

5 The national GDP, however, practically does not vary in the sensitivity analysis. The variations are -0.150 for the original analysis, -0.146 when the substitution elasticity is $10 \%$ lower, and -0.150 when that parameter has a value $10 \%$ higher. 
In the Pessimistic Scenario (RCP8.5) there is also a fall in the real GDP accumulated in 2040 for most of the 15 regions of the model, with the exception of the state of Paraná (Parana), Piauí (Piaui), Bahia, the composite region the states of Pará and Rondônia (ParaRond) and Resto do Norte (RestN). The state of Mato Grosso do Sul (MtGrSul), the region composed of the states of Santa Catarina and Rio Grande do Sul (RestS), the state of Mato Grosso (MtGrosso), and the region comprised of the states of Pernambuco and Alagoas (PernAlag), would be, in that order, those that would present the biggest drops in the real GDP in this Pessimistic Scenario. The aggregate results for the real GDP in this scenario, at the level of 6 major regions (North, Northeast, SaoPaulo, Rest of the Southeast, South and Midwest), also indicate a more pronounced decline in the South and Midwest regions (-0.12\%), while for the Northeast region the fall would be $0.01 \%$. For the other regions, there would be a fall for the Rest of the Southeast $(-0.05 \%), a$ fall for SaoPaulo $(-0.01 \%)$, and for the North region there would be a small growth of $0.01 \%$ in the real GDP.

National employment is kept fixed throughout the analysis period in all simulations. However, sectoral, and regional employment varies endogenously.

Results of the model for sectoral employment - not shown in the tables - indicate that agricultural sectors negatively affected by climate change, as well as their agro-industries, lose jobs in the Intermediate Scenario (RCP4.5) - this is the case of the sectors SojaGrao and OleoGoVegAni, for example, with falls in employment accumulated in 2040 of 22.32\% and $3.92 \%$, respectively. The opposite is true for sectors positively affected by climate change, such as CanaDeAcucar and Acucar, which registered growth in employment in the accumulated in 2040 of $3.58 \%$ and $5.51 \%$, respectively. For the Pessimistic Scenario (RCP8.5) something similar happens agricultural sectors that would register a drop in production, such as ArrozTrigOut, also lose employment (-8.65\%), and the same occurs with the associated agro-industries, BenefOPOVeg (-1.86\%) and ArrozBenef (-0.12\%). In the CanaDeAcucar and Acucar sectors, employment would grow by $1.97 \%$ and $3.10 \%$, respectively.

Table 6 shows the results of regional variation in employment and regional wages in the two climate change scenarios. All variations for employment are very small in all Brazilian regions (always between $-0.07 \%$ and $+0.07 \%$ accumulated for 2040 in either of the two scenarios portrayed). ${ }^{6}$ Regarding real wages, the relatively significant fall in MtGrosso and MtGrSul, in both scenarios, stands out.

It should be noted that regional employment does not necessarily follow the projected variation for regional GDP, since the composition of regional production, as well as the demand for labor by activity, differs among regions. It was previously verified that Mato Grosso do Sul (MtGrSul), Paraná (Parana), Mato Grosso (MtGrosso) and Bahia are the regions of the model that would present the biggest losses in the real GDP in the Intermediate Scenario, however, except for the case of Paraná (where employment would grow slightly, $0.03 \%$ ), these states would also be the ones that recorded the biggest job losses in the Intermediate Scenario. For the Pessimistic Scenario (RCP8.5), regional employment, in most cases, follows the behavior of the real GDP. The state of Paraná would present the greatest expansion in employment in this scenario, similarly to what would happen with the real GDP in the same scenario.

6 Small variations for this variable were also found in Silva et al. (2017). The authors present the results obtained for employment in six Brazilian regions. All the values found in that study were between $-0.03 \%$ and $+0.18 \%$ accumulated in 2035 (final year of the analysis of that study). 
Table 6 - Variation (\%) in employment and in average regional real wages (accumulated values up to 2040)

\begin{tabular}{lcccc} 
& \multicolumn{2}{c}{ Intermediate Scenario (RCP4.5) } & \multicolumn{2}{c}{ Pessimistic Scenario (RCP8.5) } \\
\cline { 2 - 5 } \multicolumn{1}{c}{ Region } & Employment & Real wage & Employment & Real wage \\
ParaRond & +0.01 & +0.02 & +0.01 & +0.02 \\
RestN & 0.00 & +0.02 & 0.00 & 0.00 \\
MaraToc & 0.00 & -0.08 & 0.00 & -0.01 \\
Piaui & -0.01 & -0.15 & 0.00 & -0.01 \\
RestNE & 0.00 & -0.02 & 0.00 & -0.07 \\
PernAlag & 0.00 & -0.01 & 0.00 & -0.12 \\
Bahia & -0.01 & -0.25 & 0.00 & -0.01 \\
MinasG & 0.00 & -0.03 & 0.00 & -0.12 \\
RestSE & 0.00 & -0.06 & 0.00 & -0.13 \\
SaoPaulo & 0.00 & -0.04 & 0.00 & -0.07 \\
Parana & -0.12 & +0.05 & +0.40 \\
RestS & +0.03 & +0.12 & -0.03 & -0.43 \\
MtGrSul & +0.01 & -1.12 & -0.02 & -0.53 \\
MtGrosso & -0.06 & -0.98 & -0.01 & -0.18 \\
RestCO & -0.07 & +0.02 & 0.00 & -0.04 \\
\hline
\end{tabular}

Source: Model results.

Table 7 shows that the real household consumption in the Intermediate Scenario (RCP4.5) accumulated for 2040 falls in comparison with the reference scenario - without climatic shock - for all income categories in all regions of Brazil. The fall is more intense in the states of Mato Grosso (MtGrosso) and Mato Grosso do Sul (MtGrSul), for all income classes (POF1 to POF10). ${ }^{7}$ Following are the states of Bahia and Piauí (Piaui), with much more moderate falls. As all these states, in addition to having a large share of agriculture in their economies, are also important soybean producers (especially Mato Grosso and Mato Grosso do Sul), this drop in household consumption in these four states is greatly influenced by the drop in the apt area, followed by a drop in production and in the export of this oilseed, with a consequent drop in real wages and the real GDP. In addition, simulation results for Brazil as a whole - not shown in the tables - suggest that the drop in real household consumption in this Intermediate Scenario is likely to occur slightly more intensely for the lower income categories.

Table 7 - Variation (\%) in real household consumption by region and by income categories (accumulated values for 2040) - Intermediate Scenario (RCP4.5)

\begin{tabular}{lllllllllll}
\multicolumn{1}{c}{ Regions } & POF1 & POF2 & POF3 & POF4 & POF5 & POF6 & POF7 & POF8 & POF9 & POF10 \\
ParaRond & -0.05 & -0.05 & -0.05 & -0.05 & -0.05 & -0.05 & -0.05 & -0.05 & -0.04 & -0.04 \\
RestN & -0.05 & -0.04 & -0.04 & -0.05 & -0.04 & -0.05 & -0.04 & -0.06 & -0.04 & -0.04 \\
MaraToc & -0.17 & -0.17 & -0.16 & -0.15 & -0.16 & -0.16 & -0.14 & -0.15 & -0.15 & -0.13 \\
Piaui & -0.22 & -0.23 & -0.23 & -0.23 & -0.23 & -0.22 & -0.24 & -0.23 & -0.23 & -0.22 \\
RestNE & -0.08 & -0.08 & -0.08 & -0.08 & -0.09 & -0.09 & -0.10 & -0.09 & -0.09 & -0.09 \\
PernAlag & -0.05 & -0.06 & -0.07 & -0.06 & -0.07 & -0.08 & -0.07 & -0.08 & -0.08 & -0.08 \\
\hline
\end{tabular}

Source: Model results.

7 POF1, ranges from 0 to 2 minimum wages; POF2, more than 2 to 3; POF3, more than 3 to 5 ; POF4, from more than 5 to 6; POF5, more than 6 to 8; POF6, from more than 8 to 10; POF7, from more than 10 to 15; POF8, from more than 15 to 20; POF9, from more than 20 to 30; and POF10, above 30 minimum wages. The minimum wage in Brazil in 2010 was R\$ 510.00 per month (approximately US\$290.00 dollars, considering the average rate of the American currency in 2010 , US\$1.00 $=\mathrm{R} \$ 1.76)$. 
Table 7 - Continued...

\begin{tabular}{lcccccccccc} 
Regions & POF1 & POF2 & POF3 & POF4 & POF5 & POF6 & POF7 & POF8 & POF9 & POF10 \\
Bahia & -0.33 & -0.33 & -0.34 & -0.32 & -0.32 & -0.33 & -0.32 & -0.32 & -0.32 & -0.32 \\
MinasG & -0.12 & -0.09 & -0.10 & -0.10 & -0.06 & -0.11 & -0.10 & -0.10 & -0.10 & -0.09 \\
RestSE & -0.13 & -0.12 & -0.12 & -0.12 & -0.12 & -0.13 & -0.12 & -0.11 & -0.13 & -0.13 \\
SaoPaulo & -0.10 & -0.09 & -0.08 & -0.06 & -0.11 & -0.11 & -0.11 & -0.10 & -0.11 & -0.10 \\
Parana & 0.12 & -0.18 & -0.14 & -0.14 & -0.22 & -0.18 & -0.22 & -0.26 & -0.13 & -0.14 \\
RestS & +0.10 & +0.09 & +0.09 & +0.07 & +0.07 & +0.06 & +0.10 & +0.10 & +0.04 & +0.07 \\
MtGrSul & -1.29 & -1.32 & -1.28 & -1.27 & -1.31 & -1.25 & -1.30 & -1.14 & -1.25 & -1.20 \\
MtGrosso & -1.12 & -1.11 & -1.11 & -1.11 & -1.10 & -1.11 & -1.15 & -1.14 & -1.15 & -1.09 \\
RestCO & -0.01 & -0.01 & -0.02 & -0.03 & -0.04 & -0.03 & -0.02 & -0.04 & -0.03 & -0.04 \\
\hline
\end{tabular}

Source: Model results.

Table 8 shows the variation in real household consumption in the accumulated for 2040 in the Pessimistic Scenario (RCP8.5). Household consumption falls in this scenario for most income categories and in almost all regions of Brazil, with the exception of ParaRond, RestN, MaraToc, Piaui, Bahia and Parana. In these places, increases in real household consumption for different income categories predominate, compared to the baseline scenario. For the regions that registered a decline, we note that real household consumption in this scenario, in general, should fall more for lower income categories, compromising more the well-being of these groups of poorer households. In cases where there is an increase in real household consumption, climate change causes greater gains in well-being for the higher income classes than for those with lower income, with the exception of the state of Paraná (Parana). In other words, in the Pessimistic Scenario (RCP8.5), climate change, in general, worsens the well-being of lower-income groups more than those of higher income.

Table 8 - Variation (\%) in real household consumption by region and by income categories (accumulated values for 2040) - Pessimistic Scenario (RCP8.5)

\begin{tabular}{lrlllllllll}
\multicolumn{1}{c}{ Regions } & POF1 & POF2 & POF3 & POF4 & POF5 & POF6 & POF7 & POF8 & POF9 & POF10 \\
ParaRond & +0.03 & +0.04 & +0.04 & +0.05 & +0.05 & +0.05 & +0.05 & +0.05 & +0.06 & +0.07 \\
RestN & +0.02 & +0.02 & +0.03 & +0.03 & +0.03 & +0.03 & +0.03 & +0.04 & +0.04 & +0.04 \\
MaraToc & 0.00 & +0.01 & +0.01 & +0.01 & +0.02 & +0.02 & +0.02 & +0.02 & +0.02 & +0.03 \\
Piaui & 0.00 & +0.01 & +0.01 & +0.02 & +0.01 & +0.02 & +0.01 & +0.03 & +0.02 & +0.04 \\
RestNE & -0.05 & -0.05 & -0.05 & -0.04 & -0.04 & -0.03 & -0.03 & -0.03 & -0.03 & -0.02 \\
PernAlag & -0.12 & -0.11 & -0.10 & -0.10 & -0.09 & -0.09 & -0.09 & -0.07 & -0.09 & -0.08 \\
Bahia & -0.01 & 0.00 & +0.03 & +0.02 & +0.03 & +0.05 & +0.05 & +0.06 & +0.06 & +0.08 \\
MinasG & -0.12 & -0.11 & -0.11 & -0.10 & -0.09 & -0.10 & -0.09 & -0.09 & -0.09 & -0.07 \\
RestSE & -0.12 & -0.14 & -0.14 & -0.12 & -0.12 & -0.12 & -0.11 & -0.11 & -0.10 & -0.09 \\
SaoPaulo & -0.06 & -0.07 & -0.06 & -0.07 & -0.06 & -0.05 & -0.04 & -0.04 & -0.03 & -0.02 \\
Parana & +0.60 & +0.47 & +0.49 & +0.49 & +0.46 & +0.47 & +0.47 & +0.46 & +0.49 & +0.49 \\
RestS & -0.60 & -0.49 & -0.49 & -0.49 & -0.48 & -0.43 & -0.47 & -0.49 & -0.39 & -0.40 \\
MtGrSul & -0.60 & -0.57 & -0.56 & -0.56 & -0.57 & -0.54 & -0.56 & -0.50 & -0.52 & -0.50 \\
MtGrosso & -0.16 & -0.16 & -0.15 & -0.16 & -0.15 & -0.15 & -0.16 & -0.15 & -0.16 & -0.14 \\
RestCO & -0.02 & -0.02 & -0.02 & -0.01 & -0.01 & -0.01 & -0.02 & 0.00 & 0.00 & 0.00 \\
\hline Source:Mode & & & & & & & & & &
\end{tabular}

Source: Model results.

\section{Final remarks}

This article analyzed the potential socio-economic impacts that climate change projected for 2040 may have on agriculture and on the Brazilian economy as a whole and its different regions. 
The main conclusion is that climate change - by leading to losses of areas suitable for different agricultural crops in Brazil - should cause a retraction in the real GDP, in both scenarios, but especially in the Intermediate (RCP4.5). This is because, in the Intermediate Scenario, the adopted shocks of apt area loss - as a result of climate models - are greater in absolute terms. In other words, in the absence of measures to adapt or mitigate the potential losses of suitable areas (low-risk) in Brazil caused by climate change, there is a downward trend - albeit moderate - in the level of economic activity in the country, compared to the reference scenario.

The results at the regional level suggest that the losses will be greater for those regions whose economies are more dependent on agriculture in the composition of their production value, confirming the hypothesis raised in the study's proposal, especially in those more dependent on soybean. In general, the results, in line with the existing literature, reinforce the importance of undertaking efforts in regionally disaggregated analyses when addressing the impacts of climate change, especially in the case of countries of great territorial extension such as Brazil. They show that the impacts of climate change on agriculture, in addition to not being distributed equally around the world, as already pointed out in previous international literature, also tend not to be equally distributed even among different regions of the same country. Therefore, in addition to the need for further country-specific studies on this important issue, especially for developing economies, it is also highly recommended to devote greater attention to regional differences within these national economies in future research efforts.

Finally, the results suggest that the negative impacts of climate change will be more intense on workers and poorer households, especially in the Midwest and part of the Northeast of Brazil (in the part where soybean is more representative), which should have their consumption and well-being more intensely affected than workers and households in other regions of Brazil. These have been dynamic regions in terms of the recent development of Brazilian agriculture, but the results presented here suggest that this dynamic may change in the face of climate change scenarios, bringing to the debate new considerations about the need for compensatory public policies.

The results of the study also point to the importance of maintaining and strengthening the institutional apparatus for facing the problem of climate change in Brazil, aiming to minimize its negative impacts in the upcoming decades. In this regard, it is emphasized, for example, in the field of mitigation, the importance of initiatives such as the ABC Plan (Low Carbon Agriculture) led by Embrapa, in partnership with other institutions, aiming at reducing the emission of greenhouse gases (GHG). In the field of adaptation, the relevance of continuing and strengthening support for agricultural research in Brazil, through the National Agricultural Research System (SNPA), is highlighted as an important strategy for adapting to the effects of climate change, in particular, with a view to the development of agricultural varieties that are more resistant and better adapted to the new climatic conditions projected for each region of Brazil in the upcoming decades.

\section{References}

Ahmed, S. A., Diffenbaugh, N. S., Hertel, T. W., Lobell, D. B., Ramankutty, N., Rios, A. R., \& Rowhani, P. (2011). Climate volatility and poverty vulnerability in Tanzania. Global Environmental Change, 21(1), 46-55.

Araújo, P. H. C., Silva, F. F., Gomes, M. F. M., Féres, J. G., \& Braga, M. J. (2014). Uma análise do impacto das mudanças climáticas na produtividade agrícola da região nordeste do Brasil. Revista Economica do Nordeste, 45(3), 46-57. 
Assunção, J., \& Chein, F. (2016). Climate change and agricultural productivity in Brazil: future perspectives. Environment and Development Economics, 21(5), 581-602.

Brasil. Ministério da Ciência, Tecnologia e Inovação - MCTI. Secretaria de Políticas e Programas de Pesquisa e Desenvolvimento. Coordenação-Geral de Mudanças Globais de Clima. (2016). Modelagem climática e vulnerabilidades setoriais: a mudança do clima no Brasil. Brasília: MCTI.

Brasil. Presidência da República. Secretaria de Assuntos Estratégicos - SAE. (2015). Brasil 2040, Resumo Executivo. Brasília: SAE. Retrieved in 2018, December 5, from http://www.mma. gov.br/images/arquivo/ 80182/BRASIL-2040-Resumo-Executivo.pdf

Cera, J. C., Streck, N. A., Fensterseifer, C. A. J., Ferraz, S. E. T., Bexaira, K. P., Silveira, W. B., \& Cardoso, A. P. (2017). Soybean yield in future climate scenarios for the state of Rio Grande do Sul, Brazil. Pesquisa Agropecuária Brasileira, 52(6), 380-392.

Chalise, S., \& Naranpanawa, A. (2016). Climate change adaptation in agriculture: a computable general equilibrium analysis of land-use change in Nepal. Land Use Policy, 59, 241-250.

Chalise, S., Naranpanawa, A., Bandara, J. S., \& Sarker, T. (2017). A general equilibrium assessment of climate change-induced loss of agricultural productivity in Nepal. Economic Modelling, 62, 43-50.

Cline, W. R. (2007). Global warming and agriculture: impact estimates by country. Washington, DC: Center for Global Development/Peterson Institute for International Economics.

Cruz, J. L., Alves, A. A. C., LeCain, D. R., Ellis, D. D., \& Morgan, J. A. (2016). Elevated CO2 concentrations alleviate the inhibitory effect of drought on physiology and growth of cassava plants. Scientia Horticulturae, 210, 122-129.

Darwin, R., Tsigas, M., Lewandrowski, J., \& Raneses, A. (1995). World agriculture and climate change: economic adaptations (Agriculture Economic Report, AER-703). USDA, Washington, DC.

Deconto, J. G. (Coord.) (2008). Aquecimento global ea nova geografia da produção agrícola no Brasil. Campinas: EMBRAPA/UNICAMP.

Diniz, T. B. (2019). Impactos econômicos e regionais dos investimentos em geração de energia elétrica no Brasil (Tese de doutorado). Escola Superior de Agricultura "Luiz de Queiroz", Universidade de São Paulo, Piracicaba.

Diniz, T., \& Ferreira Filho, J. B. S. (2015). Impactos Econômicos do Código Florestal Brasileiro: uma discussão à luz de um modelo computável de equilíbrio geral. Revista de Economia e Sociologia Rural, 53(2), 229-250.

Domingues, E. P., Haddad, E. A., Perobelli, F. S., Azzoni, C. R., Guilhoto, J. J. M., Kankzuc, F., \& Almeida, E. S. (2010). Impactos econômicos das mudanças climáticas no Brasil. In Anais do XXXVIII Encontro Nacional de Economia, Niterói: ANPEC.

Domingues, E. P., Magalhães, A. S., \& Ruiz, R. M. (2008). Cenários de mudanças climáticas e agricultura no Brasil: impactos econômicos na região Nordeste (Texto para Discussão, 340). Belo Horizonte: Cedeplar.

Eboli, F., Parrado, R., \& Roson, R. (2010). Climate-change feedback on economic growth: explorations with a dynamic general equilibrium model. Environment and Development Economics, 15(5), 515-533.

Elshennawy, A., Robinson, S., \& Willenbockel, D. (2016). Climate change and economic growth: An intertemporal general equilibrium analysis for Egypt. Economic Modelling, 52, 681-689. 
Fachinello, A. L., \& Ferreira Filho, J. B. S. (2010). Gripe aviária no Brasil: uma análise econômica de equilíbrio geral. Revista de Economia e Sociologia Rural, 48(3), 539-566.

Féres, J., Reis, E., \& Speranza, J. (2009). Mudanças climáticas globais e seus impactos sobre os padrões de uso do solo no Brasil. In Anais do XXXVII Encontro Nacional de Economia. Niterói: ANPEC.

Ferreira Filho, J. B. S., \& Horridge, M. (2014). Ethanol expansion and indirect land use change in Brazil. Land Use Policy, 36, 595-604.

Ferreira Filho, J. B. S., \& Moraes, G. I. (2015). Climate change, agriculture and economic effects on different regions of Brazil. Environment and Development Economics, 20(1), 37-56.

Ferreira Filho, J. B. S., Pinto, L. F. G., Faria, V. G., \& Sparovek, G. (2018). Environmental and welfare impacts of deforestation reduction in Brazil. In Annals of 21th Annual Conference on Global Economic Analysis. Purdue: GTAP.

Ferreira Filho, J. B. S., Ribera, L., \& Horridge, M. (2015). Deforestation control and agricultural supply in Brazil. American Journal of Agricultural Economics, 97(2), 589-601.

Fischer, G., Shah, M., \& Velthuizen, H. V. (2002). Climate change and agricultural vulnerability (Special Report). Vienna: International Institute for Applied Systems Analysis to World Summit on Sustainable Development.

Fundação Centro de Estudos do Comércio Exterior - FUNCEX. (2018). Indicadores. Rio de Janeiro: FUNCEX. Retrieved in 2018, October 25, from http://www.funcexdata.com.br

Haddad, E. A., Porsse, A. A., \& Pereda, P. C. (2013). Regional economic impacts of climate anomalies in Brazil. Revista Brasileira de Estudos Regionais e Urbanos, 7(2), 19-33.

Horridge, M. (2012). The TERM model and its database. In G. Wittwer (Ed.), Economic modeling of water: the Australian CGE experience. (pp. 13-35). Dordrecht: Springer.

Horridge, M., Madden, J., \& Wittwer, G. (2005). The impact of the 2002-2003 drought on Australia. Journal of Policy Modeling, 27(3), 285-308.

Instituto Brasileiro de Geografia e Estatística - IBGE. (2018a). Projeções da População do Brasil e Unidades da Federação por sexo e idade: 2010-2060. Rio de janeiro: IBGE. Retrieved in 2018, November 9, from https://www.ibge.gov.br/estatisticas-novoportal/sociais/populacao/ 9109-projecao-da-populacao.html?= \&t=resultados

Instituto Brasileiro de Geografia e Estatística - IBGE. (2018b). Séries históricas e estatísticas. Rio de janeiro: IBGE. Retrieved in 2018, October 25, from http://seriesestatisticas.ibge.gov.br

Instituto Brasileiro de Geografia e Estatística - IBGE. (2018c). Sistema IBGE de recuperação automática - SIDRA. Rio de Janeiro: IBGE. Retrieved in 2018, October 25, from http://www. sidra.ibge.gov.br/

Intergovernmental Panel on Change Climate - IPCC. (2007). Climate change 2007: synthesis report. Contribution of Working Groups I, II and III to the Fourth Assessment Report of the Intergovernmental Panel on Climate Change. Geneva, Switzerland: IPCC.

Intergovernmental Panel on Change Climate - IPCC. (2014). Summary for policymakers. Contribution of Working Group II to the Fifth Assessment Report of the Intergovernmental Panel on Climate Change. Cambridge: Cambridge University Press.

Ipeadata. (2019). Base de dados do IPEA: dados macroeconômicos. Retrieved in 2019, September 21, from http://www.ipeadata.gov.br/ 
Marin, F. R., Jones, J. W., Singels, A., Royce, F., Assad, E. D., Pellegrino, G. Q., \& Justino, F. (2013). Climate change impacts on sugarcane attainable yield in southern Brazil. Climatic Change, 117(1), 227-239.

Mendelsohn, R. (2000). Measuring the effect of climate change on developing country agriculture. In Food and Agriculture Organization of the United Nations - FAO. Two essays on climate change and agriculture: a developing country perspective (FAO Economic and Development Paper, No. 145). Rome: FAO. Retrieved in 2018, May 24, from http://www.fao.org/3/ x8044e/ x8044e00.htm/

Mendelsohn, R., \& Dinar, A. (1999). Climate change, agriculture, and developing countries: does adaptation matter? The World Bank Research Observer, 14(2), 277-293.

Nazareth, M. S., Cunha, D. A., \& Gurgel, A. C. (2018). Economic effects of projected changes productivity in the agricultural crops. In Anais do XVI Encontro Nacional da Associação Brasileira de Estudos Regionais e Urbanos. Caruaru: ABER.

Nobre, C. A., \& Assad, E. D. (2005). Aquecimento global e o impacto na Amazônia e na agricultura Brasileira. São José dos Campos: INPE. Retrieved in 2012, September 15, from http://www. sid. inpe. br/ePrint

Pavão, A. R., \& Ferreira Filho, J. B. S. (2011). Impactos econômicos da introdução do milho Bt11 no Brasil: uma abordagem de equilíbrio geral inter-regional. Revista de Economia e Sociologia Rural, 49(1), 81-108.

Pires, G. F., Abrahão, G. M., Brumatti, L. M., Oliveira, L. J. C., Costa, M. H., Liddicoat, S., Kato, E., \& Ladle, R. J. (2016). Increased climate risk in Brazilian double cropping agriculture systems: Implications for land use in Northern Brazil. Agricultural and Forest Meteorology, 228-229, 286-298.

Quiroga, S., \& Iglesias, A. (2007). Projections of economic impacts of climate change in agriculture in Europe. Economía Agraria y Recursos Naturales-Agricultural and Resource Economics, $7(14), 65-82$.

Sanghi, A., Alves, D., Evenson, R., \& Mendelsohn, R. (1997). Global warming impacts on Brazilian agriculture: estimates of the Ricardian model. Economia Aplicada, 1(1), 7-33.

Santos, C. V. (2006). Política tributária, nível de atividade econômica e bem-estar: lições de um modelo de equilíbrio geral inter-regional(Tese de doutorado). Escola Superior de Agricultura "Luiz de Queiroz", Universidade de São Paulo, Piracicaba.

Santos, C. V., \& Ferreira Filho, J. B. S. (2007). Efeitos potenciais da política tributária sobre o consumo de alimentos e insumos agropecuários: uma análise de equilíbrio geral interregional. Revista de Economia e Sociologia Rural, 45(4), 921-962.

Santos, J. A., \& Ferreira Filho, J. B. S. (2017). Substituição de combustíveis fósseis por etanol e biodiesel no Brasil e seus impactos econômicos: uma avaliação do Plano Nacional de Energia de 2030. Pesquisa e Planejamento Economico, 47(3), 185-216.

Santos, R. S., Costa, L. C., Sediyama, G. C., Leal, B. G., Oliveira, R. A., \& Justino, F. B. (2011). Avaliação da relação seca/produtividade agrícola em cenário de mudanças climáticas. Revista Brasileira de Meteorologia, 26(2), 313-321.

Silva, D. I., \& Ferreira Filho, J. B. S. (2018). Impactos dos programas de transferência de renda Benefício de Prestação Continuada e Bolsa Família sobre a economia brasileira: uma análise de equilíbrio geral. Pesquisa e Planejamento Economico, 48(1), 161-183. 
Silva, J. G., Ruviaro, C. F., \& Ferreira Filho, J. B. S. (2017). Livestock intensification as a climate policy: lessons from the Brazilian case. Land Use Policy, 62, 232-245.

Souza, B. S. (2018). Mudanças climáticas no Brasil: efeitos sistêmicos sobre a economia brasileira provenientes de alterações na produtividade agrícola (Dissertação de mestrado). Faculdade de Economia, Administração e Contabilidade, Universidade de São Paulo, São Paulo.

Tanure, T. M. P., Miyajima, D. N., Magalhães, A. S., Domingues, E. P., \& Carvalho, T. S. (2020). The impacts of climate change on agricultural production, land use and economy of the legal Amazon Region between 2030 and 2049. Economía, 21(1), 73-90.

Tavares, P. S., Giarolla, A., Chou, S. C., de Paula Silva, A. J., \& de Arruda Lyra, A. (2018). Climate change impact on the potential yield of Arabica coffee in southeast Brazil. Regional Environmental Change, 18(3), 873-883.

Verhage, F. Y. F., Anten, N. P. R., \& Sentelhas, P. C. (2017). Carbon dioxide fertilization offsets negative impacts of climate change on Arabica coffee yield in Brazil. Climatic Change, 144(4), 671-685.

Walter, L. C., Streck, N. A., Rosa, H. T., Ferraz, S. E. T., \& Cera, J. C. (2014). Mudanças climáticas e seus efeitos no rendimento de arroz irrigado no Rio Grande do Sul. Pesquisa Agropecuária Brasileira, 49(12), 915-924.

Wittwer, G., \& Verikios, G. (2012). Introducing dynamics to TERM. In G. Wittwer (Ed.), Economic modeling of water: the Australian CGE experience (pp. 37-55). Dordrecht: Springer.

Zhai, F., Lin, T., \& Byambadorj, E. (2009). A general equilibrium analysis of the impact of climate change on agriculture in the People's Republic of China. Asian Development Review, 26(1), 206-225. 
Annex 1A. Table 1A - Regions of the aggregate model

\begin{tabular}{ccl} 
& Aggregated region & \\
$\mathbf{1}$ & ParaRond & Pará e Rondônia \\
$\mathbf{2}$ & RestN & Amazonas, Roraima, Amapá e Acre \\
$\mathbf{3}$ & MaraToc & Maranhão e Tocantins \\
$\mathbf{4}$ & Piaui & Piauí \\
$\mathbf{5}$ & RestNE & Ceará, Rio Grande do Norte, Paraíba e Sergipe \\
$\mathbf{6}$ & PernAlag & Pernambuco e Alagoas \\
$\mathbf{7}$ & Bahia & Bahia \\
$\mathbf{8}$ & MinasG & Minas Gerais \\
$\mathbf{9}$ & RestSE & Espírito Santo e Rio de Janeiro \\
$\mathbf{1 0}$ & SaoPaulo & São Paulo \\
$\mathbf{1 1}$ & Parana & Paraná \\
$\mathbf{1 2}$ & RestS & Santa Catarina e Rio Grande do Sul \\
$\mathbf{1 3}$ & MtGrSul & Mato Grosso do Sul \\
$\mathbf{1 4}$ & MtGrosso & Mato Grosso \\
$\mathbf{1 5}$ & RestCo & Goiás e Distrito Federal \\
\hline
\end{tabular}

Annex 1B. Table 1B - Sectors (industries) of the aggregate model

\begin{tabular}{|c|c|c|c|c|c|}
\hline & \multicolumn{2}{|c|}{ Sector } & & \multicolumn{2}{|c|}{ Sector } \\
\hline & In full & Abbreviated & & In full & Abbreviated \\
\hline 1 & $\begin{array}{l}\text { Rice, wheat and other } \\
\text { cereals }\end{array}$ & ArrozTrigOut & 18 & $\begin{array}{l}\text { Vegetable and animal } \\
\text { oils and fats }\end{array}$ & OleoGoVegAni \\
\hline 2 & Grain maize & MilhoGrao & 19 & Processed coffee & CafeProcess \\
\hline 3 & Cotton and other fibers & AlgodHerb & 20 & $\begin{array}{l}\text { Processed rice and rice } \\
\text { products }\end{array}$ & ArrozBenef \\
\hline 4 & Sugarcane & CanaDeAcucar & 21 & $\begin{array}{l}\text { Processing of oils } \\
\text { and other vegetable } \\
\text { products }\end{array}$ & BenefOPOVeg \\
\hline 5 & Soybean & SojaGrao & 22 & Textile and leather & TextilCouro \\
\hline 6 & $\begin{array}{l}\text { Other temporary crop } \\
\text { products }\end{array}$ & OutPrLavTemp & 23 & $\begin{array}{l}\text { Wood, furniture, pulp, } \\
\text { paper, printing }\end{array}$ & MadMobCePaGr \\
\hline 7 & Coffee beans & CafeGrao & 24 & $\begin{array}{l}\text { Fuels, other refining } \\
\text { products }\end{array}$ & CombOleOPRef \\
\hline 8 & $\begin{array}{l}\text { Other permanent crop } \\
\text { products }\end{array}$ & OutPrLavPerm & 25 & Chemicals & Quimicos \\
\hline 9 & $\begin{array}{l}\text { Cattle and other live } \\
\text { animals, game meat }\end{array}$ & BovOutrAnim & 26 & $\begin{array}{l}\text { Other manufactured } \\
\text { products }\end{array}$ & OutManuf \\
\hline 10 & $\begin{array}{l}\text { Milk from cows and } \\
\text { other animals }\end{array}$ & LeitVacOuAni & 27 & Metallurgy & Metalurgia \\
\hline 11 & $\begin{array}{l}\text { Pigs, poultry and eggs, } \\
\text { fishing, and aquaculture }\end{array}$ & SuiAvOvPeAO & 28 & Electro-electronics & EletEletron \\
\hline 12 & Forestry and silviculture & ExplFlorSilv & 29 & Automobiles & Automoveis \\
\hline 13 & Mining & Mineracao & 30 & $\begin{array}{l}\text { Electricity, gas, water, } \\
\text { sewage }\end{array}$ & EletGasAgEsg \\
\hline 14 & $\begin{array}{l}\text { Oil, natural gas and } \\
\text { support services }\end{array}$ & PetroGasNat & 31 & Construction industry & Construcao \\
\hline 15 & Meats & Carnes & 32 & Trade & Comercio \\
\hline 16 & Sugar & Acucar & 33 & Transportation & Transporte \\
\hline 17 & $\begin{array}{l}\text { Dairy products, } \\
\text { beverages, and other } \\
\text { food products }\end{array}$ & LatAlimBebOA & 34 & Services & Servicos \\
\hline
\end{tabular}

